\title{
Development Audio-Visual Learning Media of Hydroponic System on Biotechnology Topic For Senior High Schools
}

\author{
Nurul Asikin \\ Maritime University of Raja Ali Haji, \\ Tanjungpinang, Indonesia \\ nasikin07@yahoo.com
}

\author{
Entin Daningsih \\ Tanjungpura University, \\ Pontianak, Indonesia
}

\begin{abstract}
Learning media is one of the important aspects of supporting learning processes. This research development aims at producing audio-visual learning media of hydroponic system on biotechnology topic which are valid and effective. The development model used is a modified 4D development model. The data collected came from the subject experts, media specialists, and teachers as practitioners in the field using the media. The data collection instruments were in the form of questionnaires and interviews. The data were analyzed by the using descriptive qualitative and the descriptive statistics. The study was tested to the biology teachers from twelve senior high schools by using a questionnaire based on the seven criteria (in conformity with the learning objectives, the learners, the characteristics of the appeal, the time of purchase, the media cost, ease of use, and the context of use). The audio-visual learning media of hydroponic system developed was categorized as the very effective learning medium $(\mathbf{8 8 . 1 7 \%})$ in the high schools and fulfilled all of the criteria.
\end{abstract}

Keywords_Learning media, audio-visual, hydroponic system, biotechnology

\section{INTRODUCTION}

Education is a process of changing attitudes and behavior of a person or group of people in an attempt to mature human beings through the efforts of learning and teaching. Education as a conscious and planned effort in facing serious challenges is aimed at producing quality human resources output. Education which is held in each education unit starting from primary education up to higher education provides the basis for shaping students' personality which in the end leads to the improvement of quality human resources.

Quality human resources are one of the characteristics of a nation's progress. National education serves to embody competent human resources by developing the skills and shaping characters and civilization of a dignified nation in the event of educating the nation. Some efforts that should be taken into account in the education sector is by reforming the education system in a planned, purposeful and sustained manner according to students' progress in an attempt to create quality education and making students capable of competing for future challenges. One of the developments that are currently taking place is the evolution of $21^{\text {st }}$-century life and knowledge.

The evolution of life and knowledge in the $21^{\text {st }}$ century brings about shifts in the characteristics, models or methods of learning. The $21^{\text {st }}$-century development is characterized by the evolution of information, computing, automation, and communication. Today's developments in science and technology require the implementation of a variety of learning processes and application of various teaching aids in schools and in other educational institutions so as to achieve the goals effectively and efficiently.

At present, teaching and learning process in schools is adapting to the development of information technology which results in a change and a shift in education paradigm [1]. This indicates that the use of information technology in the learning process in a classroom is prerequisite in nature as well as is a requirement in this global era. In order to improve the effectiveness and efficiency of learning, various media should be developed in the learning process so that the transfer of knowledge in the learning process becomes more effective and efficient [2].

The learning process is a process of communication or delivering a message of an introduction to the receiver. Learning media is the medium to convey a message (material, content, or concept) from the teacher to the learner. The use of an appealing learning media enables learners to better understand a concept. The role of an instructional media in the learning process is an important element in conveying the message or information. One of the efforts to foster creativity and motivation in utilizing information and communication technologies in improving the quality of education is by developing instructional media for a more interesting, effective and efficient learning process. One of the media that is used in the learning process is audio-visual learning media.

Audio-visual learning media is an alternative in the process of technology-based learning that enables the learning process to be optimized due to its convenience of use in the learning process, learning becomes more interesting and easy to use by learners [3]. One of the audio-visual learning media is a film wherein audio and visual of a concept or material are incorporated.

Audio-visual learning media is one of the audiovisual media which involve the senses of sight and hearing. According to Pastore, learning by hearing and seeing can boost students' memory by $50 \%$ [4], whereas the results of research by Dwyer show that $94 \%$ of learning materials can be absorbed by the learners through the senses of sight and hearing [5]. The more senses and movement of children involved in the learning process, the more easily children 
would learn to define meanings [6]. Audio-visual learning media can be applied to the subject of biology.

Biology is a science that was developed through analytical thinking skills, inductive and deductive skills in identifying and solving problems related to the surrounding phenomenon. The object study of biology is associated with the real world which therefore learning biology as a subject in schools should be contextually offered by relating the concepts with facts that occur in students' daily lives. The materials on the subject of biology can be taught contextually with the use of instructional media. Biotechnology is one of the materials that can be taught contextually.

Based on the discussions with a biology teacher in high school, the materials on biotechnology where one of its material scopes is hydroponics are still deficient and have not been explained properly due to limited facilities and lack of instructional media, whereas in fact, these materials need to be developed since students can apply the concepts of biology to deal with issues or problems in everyday life using simple appropriate technology. However, lack of instructional media and the absence of a hydroponic system poses an obstacle to learning implementation. To overcome these barriers, an appropriate learning media is deemed great importance. One medium that can be used is the audio-visual learning media on hydroponics systems which is presented in biotechnology materials.

The development of audio-visual learning media is expected to produce feasible audio-visual media. By harnessing feasible audio-visual media in learning, it is expected that quality learning is created, thereby helps solve problems faced by students in the event of achieving optimal learning results. Based on this background, this study develops an audio-visual learning media on the hydroponic system in the subject of biotechnology which can be feasibly used and potentially improve the quality of learning.

Learning media is a method that is expected to enable students to understand the concepts of biology more easily. The instructional media used are carefully selected and adapted to the learning materials. According to Umar (2013), utilization and selection of appropriate media essentially aim to improve the efficiency and effectiveness of teaching [7]. In addition to the media appropriateness, selection and presentation of the material must be adapted to students' needs in learning, such as that of the course of hydroponic particularly in the subject of biotechnology.

\section{A. The Function of Learning Media}

Essentially, instructional media is used in the learning process in order to improve the effectiveness of communication and educational interaction between teachers and students in the classroom. According to Hamalik in Muziati (2010), media could serve as (1) establishing concrete grounds to reduce verbalism, (2) boosting students' attention in learning, (3) establishing an important basis for the development of learning and therefore makes learning more stable, (4) providing real experiences that can trigger students' individual work, (5) fostering well-organized and continuous ideas mainly in live images, (6) helping to foster students' understanding and thus help develop students' ability to learn, and (7) providing a different experience, and fostering efficiency in more diversity in learning [8].

\section{B. Different Types of Learning Media}

Bretz in Munadi (2008) classifies learning media by the senses involved, leading to three main elements which function as the basis of each media type including voice (audio), visual and motion [9]. The element of sound is the element that involves the sense of auditory, while the element of visual is the element that involves the sense of sight. However, the element of Bretz motion is not basing the motion on sensory involvement but instead on the tools that support the media.

Suryani (2006) argues that the experience gained in learning where multimedia is used encompasses the aspects of vision (visual), hearing (audio), and motion (motor) in addition to its aim of facilitating students in learning and instilling concepts [6]. The more senses and movement of students involved in the learning process, the more easily children can learn to define meanings.

Media classification based on senses is more likely due to the understanding that five senses are the golden gate of knowledge [10]. In the learning process, media can be classified into four major categories, namely audio media, visual media, audiovisual media and multimedia [9].

\section{Criteria for Selecting Media}

An instructional media is selected with the hope that either it can be used to meet the needs and achieve the desired goals or not. For that reason, basic selection criteria are needed in order to avoid dysfunction or less optimal results of the media being used. According to Rahadi (2008), there are seven criteria that must be considered in selecting instructional media, namely (a) the appropriateness to learning objectives or competence to be achieved, (b) the target of learners, (c) characteristics of the media used, (d) time, (e) costs, (f) ease of obtaining the media, (g) the context of use [11]. From the aforementioned explanation on different types of media and the advantages of each of these media, it can be concluded that the best possible option for a media to be used in this research is audio-visual learning media.

\section{MethodS}

This study uses research and development model with the product under development is an audio-visual learning media on the hydroponic system in the subject of biotechnology. The development model in this study is an adaptation of the measures of research and development of four D (4D) model as proposed by Thiagarajan, Semmel, and Semmel (1974) which consists of four main phases, namely: define, design, develop, and disseminate [12].

The define phase includes: (1) analyzing teachers who have difficulty in delivering the latest information about hydroponics to students and the teachers need a media as a means to deliver the material on biotechnology particularly on hydroponics, (2) analyzing students through interviews 
and discussions with students pertaining to the use of learning media as harnessed by teachers during the learning process of biotechnology, (3) analyzing the course of biotechnology. The design phase includes: (1) the selection of media wherein the instructional media used is the audio-visual on the hydroponics system in the course of biotechnology, (2) preparing an initial design in creating instructional media of audio-visual system on hydroponics which is composed of two parts. The first part is the use of biotechnology in improving crop production and the second part is creating an NFT (Nutrient Film Technique) hydroponic system and floating rafts. Designing the creation of audio-visual learning media on hydroponic system incorporates supplementary computer applications such as Windows Movie Maker and Ulead Video Studio 11. According to Sadiman (2008), collecting materials and setting the standard reference of audio-visual learning media with hydroponics system shall include: (a) a synopsis, (b) a storyboard, (c) the script, (d) editing, (e) voice editing and music composing (dubbing), and (f) packaging (the final step of all the above processes into a full movie), (g) converting the film into a CD [13].

The last stage is the development phase which includes validating and testing the product. The validation of the media is followed by the revision of the media. Validation phase was performed by subject matter experts and media expert validator. The pilot phase was performed by the teacher as the practitioner in the field. In this research, the teachers involved were high school biology teachers of the twelfth class selected based on random sampling of twelve people with each school represented by one biology teacher.

The data obtained from the experiment are classified into two categories, namely quantitative and qualitative data. The qualitative data in this study is in the form of suggestions and criticism, while the quantitative data are in the form of scoring on each instrument item that is filled in by subject matter experts and media experts as well as practitioners in the field.

Assessment instrument used in this study was a questionnaire on the audio-visual learning media on the hydroponic system. Questionnaires were created to examine teachers' responses towards audio-visual learning media that has been created. Media assessment instrument is based on seven criteria of a good medium, viz. learning objectives, students, characteristics, time of usage, costs, availability, and the context of usage [11].

\section{RESULTS AND DISCUSSION}

\section{A. Result}

Audio-visual learning media on the hydroponic system was created using Ulead Video Studio 11 program and was divided into two parts. The first part of the film is about the use of biotechnology in increasing crop production which lasts 6 minutes and 23 seconds and the second part of the film is about creating the hydroponic system which lasts 24 minutes and 43 seconds.

Audio-visual learning media assessment is performed by 12 high school teachers of biology at twelfth class in
Pontianak of which have been included in the random sampling out of 12 schools. A set of questionnaires is used to determine the effectiveness of audio-visual learning media. A close-ended questionnaire was used. The average score of the overall effectiveness of audio-visual learning media of hydroponic system is $88.17 \%$ (Table 1), making it categorized as highly effective.

Assessing the effectiveness of audio-visual learning media on the hydroponic system was done through questionnaires from 12 high school biology teachers. The data obtained through the questionnaire were then drawn up and were divided into seven criteria: (1) learning objectives (syllabus), (2) appropriateness to the students, (3) appealing characteristics, (4) time of usage, (5) affordable purchasing costs, (6) ease of usage, and (7) the context of usage.

TABLE I. THE TOTAL OF ASSESSMENT AND EFFECTIVENESS CATEGORY OF AUDIO-VISUAL LEARNING MEDIA ON HYDROPONIC SYSTEM

\begin{tabular}{|c|c|c|c|}
\hline Respondent & $\begin{array}{c}\text { Total } \\
\text { Assessment }\end{array}$ & $\begin{array}{c}\% \\
\text { Effectiveness }\end{array}$ & $\begin{array}{c}\text { Effectiveness } \\
\text { Category }\end{array}$ \\
\hline 1 & 91 & $91 \%$ & Highly Effective \\
\hline 2 & 89 & $89 \%$ & Highly Effective \\
\hline 3 & 79 & $79 \%$ & Very Effective \\
\hline 4 & 94 & $94 \%$ & Highly Effective \\
\hline 5 & 91 & $91 \%$ & Highly Effective \\
\hline 6 & 93 & $93 \%$ & Highly Effective \\
\hline 7 & 83 & $83 \%$ & Highly Effective \\
\hline 8 & 99 & $99 \%$ & Highly Effective \\
\hline 9 & 89 & $89 \%$ & Highly Effective \\
\hline 10 & 79 & $79 \%$ & Very Effective \\
\hline 11 & 93 & $93 \%$ & Highly Effective \\
\hline 12 & 78 & $78 \%$ & Very Effective \\
\hline \multicolumn{2}{|c|}{ Average } & $88,17 \%$ & Highly Effective \\
\hline
\end{tabular}

The results of the effectiveness assessment of audio-visual learning media on the hydroponic system based on overall criteria of media effectiveness can be shown in Table II.

TABLE II. RESULTS OF OVERALL EFFECTIVENESS ASSESSMENT OF AUDIOVISUAL LEARNING MEDIA ON HYDROPONIC SYSTEM BASED ON CRITERIA OF MEDIA EFFECTIVENESS

\begin{tabular}{|c|c|c|c|}
\hline $\begin{array}{l}\mathbf{N} \\
\mathbf{0}\end{array}$ & Criteria & $\begin{array}{c}\text { Percenta } \\
\text { ge }(\%)\end{array}$ & Category \\
\hline 1 & $\begin{array}{l}\text { Audio-visual learning media on } \\
\text { hydroponic system is in line with the } \\
\text { learning objectives }\end{array}$ & 100 & $\begin{array}{l}\text { Highly } \\
\text { Effective }\end{array}$ \\
\hline 2 & $\begin{array}{c}\text { Audio-visual learning media on } \\
\text { hydroponic system is appropriate to } \\
\text { the students }\end{array}$ & 95,83 & $\begin{array}{l}\text { Highly } \\
\text { Effective }\end{array}$ \\
\hline 3 & $\begin{array}{c}\text { Audio-visual learning media on } \\
\text { hydroponic system has appealing } \\
\text { characteristics }\end{array}$ & 100 & $\begin{array}{l}\text { Highly } \\
\text { Effective }\end{array}$ \\
\hline 4 & $\begin{array}{l}\text { Audio-visual learning media on } \\
\text { hydroponic systems with the criteria } \\
\text { of usage time }\end{array}$ & 94,44 & $\begin{array}{l}\text { Highly } \\
\text { Effective }\end{array}$ \\
\hline 5 & $\begin{array}{l}\text { The purchasing cost of audio-visual } \\
\text { learning media on hydroponic system }\end{array}$ & 95,83 & $\begin{array}{l}\text { Highly } \\
\text { Effective }\end{array}$ \\
\hline 6 & $\begin{array}{c}\text { Ease of use of audio-visual learning } \\
\text { media on hydroponic system }\end{array}$ & 88,89 & $\begin{array}{l}\text { Highly } \\
\text { Effective }\end{array}$ \\
\hline 7 & Context of usage & 100 & $\begin{array}{l}\text { Highly } \\
\text { Effective }\end{array}$ \\
\hline
\end{tabular}




\section{B. Discussion}

Based on the evaluation performed by 12 high school biology teachers, audio-visual learning media on hydroponic systems provides highly effective $(88.17 \%)$ medium of learning in high school. This is supported by the respondents' assessment on the audio-visual learning media on the hydroponic system which is categorized as highly effective as a learning medium (Table 1). As such, the respondents considered that the audio-visual learning media generally correspond to the learning objectives, appropriate to the students, has appealing characteristics, efficient time of usage, affordable purchasing cost, ease of usage and in line with the context of usage.

\section{1) In line with the Learning Objectives}

In terms of target appropriateness, the effectiveness of audio-visual learning media on hydroponic system corresponds to the learning objectives wherein $100 \%$ of respondents agree that audio-visual learning media on hydroponic systems meet the target of learning objectives. Audio-visual learning media as a learning medium is appropriate to retell hydroponics, the advantages of hydroponics, different types of hydroponic systems as well as the steps in preparing a hydroponic system so that the learning objectives in the syllabus can be achieved. This is also supported by the remarks on the suggestions/commentary forms filled by the respondents in which they state that audiovisual learning media is in accordance with the syllabus indicators to be achieved. According to Anderson (1987) in Munadi (2008), the relationship between audio-visual teaching media and the learning objectives is that audiovisual media is aimed at cognitive purposes which can be used to teach meaning introduction of a concept [9].

\section{2) Appropriate to the Students}

In terms of the criteria of target students, the respondents agree that the audio-visual learning media on the hydroponic system is appropriate to the students by $95.83 \%$. This is supported by the remarks of the respondent in suggestions/commentary form in the questionnaire which stated that the audio-visual learning media on the hydroponic system is appropriate to the students wherein the materials covered in the audio-visual learning media on the hydroponic system are easily understood by high school students with different academic abilities.

\section{3) Has Appealing Characteristics}

In terms of appealing criteria, the respondents agree that the audio-visual learning media on the hydroponic system has an appealing side to its simple design by $100 \%$. This is supported by the remarks of the respondents in suggestions/commentary form in the questionnaire distributed. Respondents stated that audio-visual learning media on hydroponics system has extra appeals than that of lecturing method in which power-point slides are used, thus through this audio-visual learning media, students can learn in an audio-visual way. This audio-visual learning media enables students to better understand the concepts to be presented by teachers and by looking at this audio-visual learning media on hydroponics system, students will become intrigued to learn things related hydroponics and ways of setting up hydroponics system

\section{4) Time of Usage}

As much as $94.44 \%$ of respondents agree that the audiovisual learning media on the hydroponic system can make time in learning activities in the classroom more efficient. This is supported by the remarks of suggestion/commentary on the questionnaire which stated that the audio-visual learning media is more efficient in comparison to doing practicum or demonstrations, in case of practicums in school cannot be done due to the shortage of equipment and materials. In addition to that, the time spent in learning is more effective since students do not conduct experiments so that students understand more easily

\section{5) Media Purchasing Costs}

Based on respondents' responses, $95.83 \%$ of them agree that audio-visual learning media on hydroponic systems can be purchased by teachers and students individually at an affordable price. Thus, this media is in general within schools' purchasing power to buy it. However, in this case, the audiovisual learning media need to undergo improvements and to be augmented by minimizing the costs incurred so as to let schools able to buy it at an affordable price. Costs incurred to get and use the media should go together with the results to be achieved.

\section{6) Ease of Usage}

Respondents agree that $(88.89 \%)$ audio-visual learning media on the hydroponic system is easy to use, while $11.11 \%$ of the total respondents less agree. This is due to the shortage of tools and materials available in the laboratory necessary to conduct experiments and the shortage of facilities in school to play films of hydroponics when learning activities are taking place in the classroom. Hence, one of the alternatives for schools with no facilities to play the audio-visual media is to borrow/collaborate with schools that have the facilities to play audio-visual learning media

\section{7) Context of Usage}

In terms of the context of use criteria, $100 \%$ of respondents agree that the use of audio-visual learning media on the hydroponic system can be used in the classroom, group learning, and self-learning. This is because the use of audiovisual learning media in the learning process can help teachers explain about hydroponics to students, and independently help teachers identify the degree of students' knowledge and understanding towards hydroponics in a theoretical basis. If it is used in groups, students can work together and exchange information on the knowledge and understandings they received. 
Audio-visual learning media on hydroponic system meet all seven criteria of instructional media requirements. The seven criteria are the media that is created in accordance with learning objectives in the syllabus, appropriate to the target students, appealing characteristics, time efficiency in the use of media, the purchasing cost, ease of usage, and the context of usage (Table 1). Thus, the audio-visual learning media on a hydroponic system is highly effective to be used as a medium of learning in the subject of biology in high school. This is line with Munadi's statement (2008), in which he states that the audiovisual learning media is a communication tool that helps make the learning process effective [9]. Prior to being used by users, the aspect of ease of use in this media needs to be improved.

From the results of effectiveness assessment of audiovisual learning media on the hydroponic system, it was discovered that the media proves to be highly effective. This leads to the need for conducting an effectiveness assessment in audio-visual learning media on hydroponic system as a medium of learning in order to find out students' understanding towards biotechnology, especially that of hydroponics. This is supported by Munadi's statement (2008), in which he states that the audio-visual media can lead to the increase in students' understanding [9].

\section{CONCLUSION}

In conclusion, this study has revealed that the evaluation results performed by 12 high school biology teachers show that audio-visual learning media on hydroponic systems are highly effective $(88.17 \%)$ as a medium of learning in high schools. Audio-visual learning media on hydroponic system meets all seven criteria of instructional media requirements, thus making it classified as highly effective when used as a medium of learning. The seven criteria are the media created in accordance with the learning objectives in the syllabus, appropriate too with the students, appealing characteristics, time efficiency in the use of media, ease of usage, purchasing cost at an affordable price and is in accordance with the context of usage.

\section{REFERENCES}

[1] Hujair AH. Sanaky, Media Pembelajaran. Yogyakarta: Safiria Insania Press, 2009.

[2] A. Muhson, "Pengembangan Media Pembelajaran Berbasis Teknologi Informasi," J. Pendidik. Akutansi Indonesia., vol. VIII, no. 2, p. 1, 2010.

[3] S. Haryoko, "Efektivitas Pemanfaatan Media Audio-Visual Sebagai Alternatif Optimalisasi Model Pembelajaran,” J. Edukasi2, vol. 5, pp. 110, 2009.

[4] Pastore, "Dele's Cone Experience," 2003. [Online]. Available: http://teacherworld.com/potdale.html.

[5] Dwyer Francis M., Strategis for Improving Visual Learning. Pensylvania: Learning Services, 1978.

[6] N. Suryani, "Pengaruh Penerapan Pendekatan Kontekstual bermedia VCD Terhadap Pencapaian Kompetensi Belajar Sejarah (Studi Eksperimen di SMA Negeri I Karanganyar dan SMA Negeri Karangpandan Tahun Pelajaran 2006/2007)," Universitas Sebelas Maret, 2006.

[7] Umar, "Media Pendidikan: Peran dan Fungsinya dalam Pembelajaran," J. Tarb., vol. 10, pp. 126-141, 2013.

[8] Muziati, "Identifikasi Bakteri Pelarut Pospat dalam Proses Pengomposan Serasah dari Lahan Pertanian dan Implementasinya dalam Pembuatan Media Film Teknik Isolasi Bakteri pada Sub Pokok Bahasan Eubakteria Kelas X SMA,” Universitas Tanjungpura, 2010.

[9] Y. Munadi, Media Pembelajaran. Jakarta: Gaung Persada Press, 2008

[10]A. Arsyad, Media Pembelajaran. Jakarta: PT. Raja Grafindo Pustaka, 2008.

[11]A. Rahadi, "Bagaimana Memilih Media Pembelajaran," 2008. [Online]. Available: https://aristorahadi.wordpress.com/2008/06/02/bagaimanamemilih-media-pembelajaran/.

[12]M. Thiagarajan, S; Semmel, D.S; \& Semmel, Instructional Development for Training Teachers of Exceptional Children: A Sourcebook. Indiana: Indiana University, 1974.

[13] Sadiman, Media Pendidikan. Jakarta: PT. Raja Grafindo Pustaka, 2008. 